\title{
Fitness Analysis Of Water Suitability For Seaeed Cultivation Kappahycus Alvarezii In South Buton Regency, Southeast Sulawesi
}

\author{
Fadhli Insani Ihsan ${ }^{1 *}$, Hasni Y. Azis², Muhammad Anshar Amran ${ }^{3}$ \\ ${ }^{1}$ Magister program of Marine Sciences and Fisheries, Hasanuddin University, Indonesia \\ ${ }^{2}$ Aquaculture Program, Hasanuddin University, Indonesia \\ ${ }^{3}$ Marine Sciences, Hasanuddin University, Indonesia \\ *Corresponding author: \\ Email: hasniazis375@gmail.com
}

\begin{abstract}
.
Seaweed cultivation in Indonesia is more focused on the production of Kappaphycus alvarezii species as a carrageenan producer. Land suitability analysis is an important stage in the preparation of spatial planning for coastal areas. This study aims to determine the appropriate location of the waters based on physical and chemical parameters using GIS. The research method is survey methods to get actual data related to seaweed cultivation activities. The spatial analysis of land suitability was carried out with a geographic information system based on the results of the $x$-weight score. The results of the analysis show that the spatial distribution that can be used for seaweed cultivation in the Batauga subdistrict is 280 ha (very suitable) and Sampolawa 519 ha (very suitable), 838 ha (suitable), 234 ha (unsuitable).
\end{abstract}

KeyWords: Seaweed, land suitability, spatial analysis.

\section{INTRODUCTION}

Seaweed is an important commodity for Indonesian marine and fisheries. Seaweed cultivation in Indonesia is more focused on the production of the Kappaphycus alvarezii species as a carrageenan producer. Within a decade, seaweed cultivation production has increased with a value of $<450$ thousand tons in 2004 than in 2014 around 10 million tons and an increase of 11.6 million tons in 2016, world seaweed production is around 30 million tons almost $40 \%$ of the total seaweed production in the world comes from Indonesia [1].

In the development, the use of the area for seaweed cultivation is still very large, it is recorded as 1.1 million ha or $9 \%$ of the total area of the potential marine cultivation area which is $12,123,383$ ha with a utilization rate of $25 \%$ [2]. The initial stage that needs to be done to utilize a potential area is a study of the suitability of waters by taking into account environmental conditions, water quality, socio-economy, infrastructure, and regional regulations.

Currently, seaweed cultivation in South Buton waters is the main source of livelihood for some coastal communities, especially in Batauga and Sampolawa 
Districts, which are the center of seaweed cultivation activities, with details in Batauga Subdistrict as many as 12 business units and in Sampolawa Subdistrict, 7 business units out of a total of 34 cultivation business unit in South Buton Regency [3]. As with other problems in coastal areas in Indonesia, South Buton Regency at the beginning of the development of seaweed cultivation has not considered land suitability, so that the potential from seaweed cultivation activities can still be increased.

By utilizing spatial analysis using Geographical Information Systems (GIS) can determine the suitability of waters and provide a comprehensive explanation of land suitability analysis. Land suitability analysis is an important stage in the preparation of spatial planning for coastal areas so that there is synergy between activities that develop in coastal areas [4]. This study aims to determine the appropriate location of the waters based on physical and chemical parameters using GIS. The results are expected to provide information in the form of a map of the suitability of cultivation locations in the South Buton Regency.

\section{METHODS}

This research was conducted in July-August 2020 in Batauga and Sampolawa Districts, South Buton District, Southeast Sulawesi Province (Fig 1). The observation station consists of 15 stations that are determined randomly (purposive random sampling) by taking into account the characteristics and utilization of the coastal waters where there are seaweed cultivation activities.

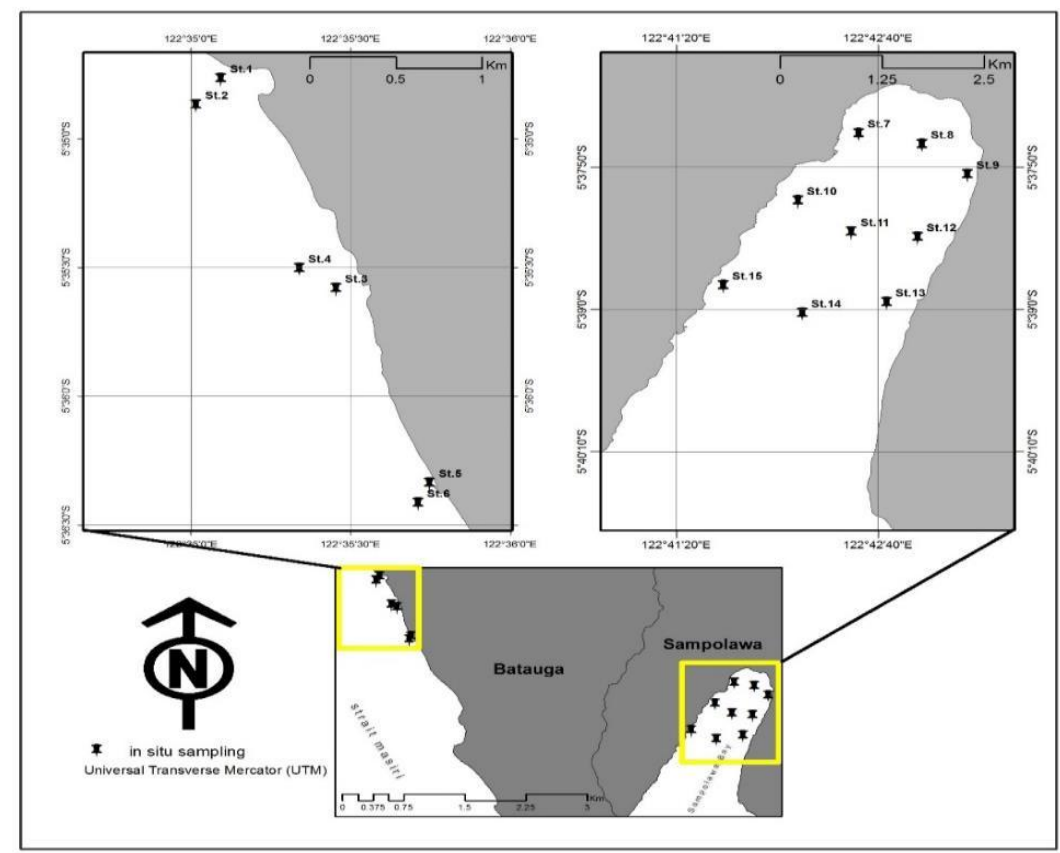

Fig 1. Site of research locations in South Buton Regency, Southeast Sulawesi Province 
Water quality data collection is carried out directly (in situ) and observations in the laboratory (ex situ). In situ water quality measurements include salinity, temperature, and current velocity, whereas exitually includes nitrate $\left(\mathrm{NO}_{3}{ }^{-} \mathrm{N}\right)$, phosphate $\left(\mathrm{PO}_{4}^{-}\right)$, ammonium $\left(\mathrm{NH}_{4}{ }^{-} \mathrm{N}\right)$, TSS (Total Solid Suspended).

Analysis of the determination of suitability is carried out by means of the weighting or scoring method through the suitability matrix. Each parameter is given a weight (B), while the range value for each of these parameters is given a score (S) as shown in the Table of Criteria for the suitability of seaweed cultivation land (Table 1) and then calculated based on weight (B) and score (S), where the total value of land suitability for seaweed cultivation $(\mathrm{NK})=\sum \mathrm{B} \times \sum \mathrm{S}$ adopts [5]

Table. 1 Physical parameters of water for the suitability of seaweed cultivation land

\begin{tabular}{|c|c|c|c|c|c|}
\hline No & Parameter & $\begin{array}{c}\text { Weight } \\
(\%)\end{array}$ & Range & Score & References \\
\hline \multirow[t]{3}{*}{1.} & Salinity (\%o) & \multirow{3}{*}{15} & $32-34$ & 3 & \multirow{3}{*}[5]{} \\
\hline & & & $28-32$ & 2 & \\
\hline & & & $<28$ atau $>35$ & 1 & \\
\hline \multirow[t]{3}{*}{2.} & Temperature $\left({ }^{\circ} \mathrm{C}\right)$ & \multirow{3}{*}{15} & $28-30$ & 3 & \multirow{3}{*}[6]{} \\
\hline & & & $26-27$ atau $33-35$ & 2 & \\
\hline & & & $<25$ atau $>35$ & 1 & \\
\hline \multirow[t]{3}{*}{3.} & Current velocity & \multirow{3}{*}{15} & $21-30$ & 3 & \multirow{3}{*}[5]{} \\
\hline & $(\mathrm{cm} / \mathrm{s})$ & & $11-19$ atau $>31-45$ & 2 & \\
\hline & & & $<11$ atau $>45$ & 1 & \\
\hline \multirow[t]{3}{*}{4.} & TSS (mg/L) & \multirow{3}{*}{10} & $<25$ & 3 & \multirow{3}{*}[7]{} \\
\hline & & & $25-50$ & 2 & \\
\hline & & & $>50$ & 1 & \\
\hline \multirow[t]{3}{*}{5.} & Nitrate $(\mathrm{mg} / \mathrm{L})$ & \multirow{3}{*}{10} & $0,9-3$ & 3 & \multirow{3}{*}[5]{} \\
\hline & & & $0,1-<0,9$ atau $3-3,5$ & 2 & \\
\hline & & & $<0,1$ atau $>3,5$ & 1 & \\
\hline \multirow[t]{3}{*}{6.} & Amonium (mg/L) & \multirow{3}{*}{10} & $0,1-2$ & 3 & \multirow[t]{3}{*}[8]{} \\
\hline & & & $0,01-<0,1$ atau $2-2,5$ & 2 & \\
\hline & & & $<0,01$ atau $>2,5$ & 1 & \\
\hline \multirow[t]{4}{*}{7.} & Phosphate (mg/L) & \multirow{4}{*}{10} & $0,02-1,0$ & 3 & \multirow{4}{*}[5]{} \\
\hline & & & $0,01-<0,02$ atau $1,0-$ & 2 & \\
\hline & & & 2,0 & 1 & \\
\hline & & & $<0,01$ atau $>3,5$ & & \\
\hline
\end{tabular}

The criteria for the suitability of seaweed cultivation

land

Conformity Value

Value 85-142 (S3) = unsuitable

Value 142-198 (S2) = Suitable

Value 198-255 (S1) = Very suitable

Parameters that play an important role in the growth of seaweed are given the greatest weight, while the value of the most suitable parameter range is also given the highest score. Based on the NK value, land suitability is classified into three class 
levels consisting of three categories, namely: S1 - very suitable, at intervals of 198 255 , S2 - suitable, with intervals of 142 - 198, and N- unsuitable to intervals of 85 142. The value of each parameter listed in Table 1 is then mapped, then each thematic map is overlaid using spatial analysis, so that it becomes one final thematic map, namely the map of the suitability distribution of seaweed cultivation land in South Buton Regency.

\section{RESULT AND DISCUSSION}

\section{Salinity}

Salinity is the amount of salt dissolved in seawater. Salinity in a water can be influenced by several factors including water circulation patterns, evaporation, rainfall, and river flow. The salinity value from the measurement results in the field obtained values ranging from 26-34 ppt. The condition of the low salinity value is due to the influence of the freshwater content originating from the upstream of the river in Sampolawa District. Kappaphycus alvarezii can grow optimally in the range of salinity values 29 - 34 ppt [9], while according to [5], optimal growth is in the range of 32-35 ppt values. Therefore, in determining the location for cultivation, it is best to avoid locations that are close to river estuaries or other fresh water sources [10].

\section{Temperature}

Seawater temperature parameters are very important environmental factors for the growth of seaweed. Based on the results of measurements in the field, it was obtained water temperature data ranging from $27.8-28.2^{\circ} \mathrm{C}$. According to [11], the temperature values range $25-31{ }^{\circ} \mathrm{C}$ has a role to increase the level of seaweed consumption so as to provide a smooth metabolic process. Change in temperature are influenced by meteorological conditions such as rainfall, evaporation, air humidity, wind speed, and sunlight intensity. Meanwhile, [12] stated that the temperature is good for the growth of seaweed Euchema cottonii is $24-31^{\circ} \mathrm{C}$ and the results of studies conducted by [13] both on a laboratory and field scale indicate that E. cottoni has a maximum photosynthetic rate at $30^{\circ} \mathrm{C}$ and experiences photosynthetic resistance in the range of values $35-40^{\circ} \mathrm{C}$.

\section{Total Solid Suspended (TSS)}

The turbidity parameter is very important because it will affect the level of light penetration that enters the water column and as a material for photosynthesis for algae. Based on the results of the analysis, the TSS values ranged from 31.76 to $48.58 \mathrm{mg} / \mathrm{L}$. The high TSS can affect the life of organisms, namely the inhibition of light penetration into the water column which causes disruption the photosynthesis process so that it can interfere with the growth of seaweed. [14] states that the TSS concentration in waters generally consists of phytoplankton, zooplankton, human activity waste, sludge, and industrial waste. Suspended solid material in natural waters is not toxic, however, if the amount is excessive, it can increase the turbidity value which further inhibits the penetration of sunlight into the water column. In the [15] 
concerning Sea Water Quality for Marine Cultivation the desired TSS value is $<25$ $\mathrm{mg} / \mathrm{L}$ and is still allowed at the level of $80 \mathrm{mg} / \mathrm{L}$. The turbidity value that is too high will prevent the penetration of sunlight into the water body.

\section{Current velocity}

Current movement is an important factor affecting the growth of seaweed. Based on the results of measurements in the field, it is obtained current velocity data in the range of $10-51 \mathrm{~cm} / \mathrm{s}$, with a maximum current speed of $51 \mathrm{~cm} / \mathrm{s}$ and a minimum of 10 $\mathrm{cm} / \mathrm{s}$. Based on [5] stated that plant growth is not disturbed by the movement of water (current) which is quite fast because it can clean plants from fine grains of sediment and epiphytes in the thallus, and can present new nutrients, get rid of metabolic waste, stimulate plant growth through force or the hydraulic strength of water movement, and preventing large fluctuations in water temperature. According to [16], a good current velocity for the cultivation of Euchema cottonii is $33-66 \mathrm{~cm} / \mathrm{s}$. [17] states that the optimum growth of $E$. cottonii seaweed occurs at a current velocity of $\pm 20 \mathrm{~cm} / \mathrm{s}$.

\section{Nitrate $\left(\mathrm{NO}_{3}^{-} \mathrm{N}\right)$}

The element of nitrate in a water is very important because nitrate shows the fertility level of a water. Based on the analysis, the nitrate concentration is around 0.05 $-0.21 \mathrm{mg} / \mathrm{L}$. [18] states that if the condition of the nitrate content is below 0.1 or above $4.5 \mathrm{mg} / \mathrm{L}$, then nitrate becomes a growth limiting factor. Based on the Decree of the State Minister for the Environment number 51 of 2004 concerning quality standards, the maximum concentration of nitrate is $0.008 \mathrm{mg} / \mathrm{L}$, and or $0.06 \mathrm{mg} / \mathrm{L} \mathrm{[19].}$

\section{Ammonium $\left(\mathrm{NH}_{4}^{-} \mathrm{N}\right)$}

Ammonium is a nitrogen source that influences the growth process of seaweed [20]. Based on the results of the analysis, the ammonium values ranged from 1.04 to $2.77 \mathrm{mg} / \mathrm{L}$ with an average of $1.48 \mathrm{mg} / \mathrm{L}$. The highest value for ammonium parameters was $2.78 \mathrm{mg} / \mathrm{L}$ and the lowest was $1.04 \mathrm{mg} / \mathrm{L}$. According to [21], the high ammonium absorbed by seaweed causes high levels of carrageenan in the seaweed.

\section{Phosphate $\left(\mathrm{PO}_{4}^{-}\right)$}

Phosphate is an essential element for higher plants and algae, so this element can be a limiting factor for aquatic plants and algae, and greatly affects the level of aquatic productivity both temporally and spatially [22]. Based on the analysis result, the phosphate values range from 0.01 to $0.03 \mathrm{mg} / \mathrm{L}$.

According to [23], the phosphate content in the waters for seaweed cultivation is $0.1-0.2 \mathrm{mg} / \mathrm{L}$. If in seawater there is a minimum of $0.01 \mathrm{mg} / \mathrm{L}$ phosphate, then the growth rate of most aquatic biota will not experience any obstacles. However, if the phosphate level falls below this critical level, the cell growth rate will decrease further [24].

\section{Seaweed Cultivation Suitability Map}

Based on the results of spatial analysis (overlay) the suitability of waters for seaweed cultivation based on determinants of seaweed growth shows the spatial 
distribution that can be used for seaweed cultivation. Based on Figure 2, the water area is included in the S1 class category (very suitable) with the area in Batauga Subdistrict 280 ha and Sampolawa Subdistrict with an area of 519 ha, class S2 (Suitable) with an area of 838 ha in Sampolawa Subdistrict, and class S3 (unsuitable) covering an area of 234 ha in Sampolawa Subdistrict.

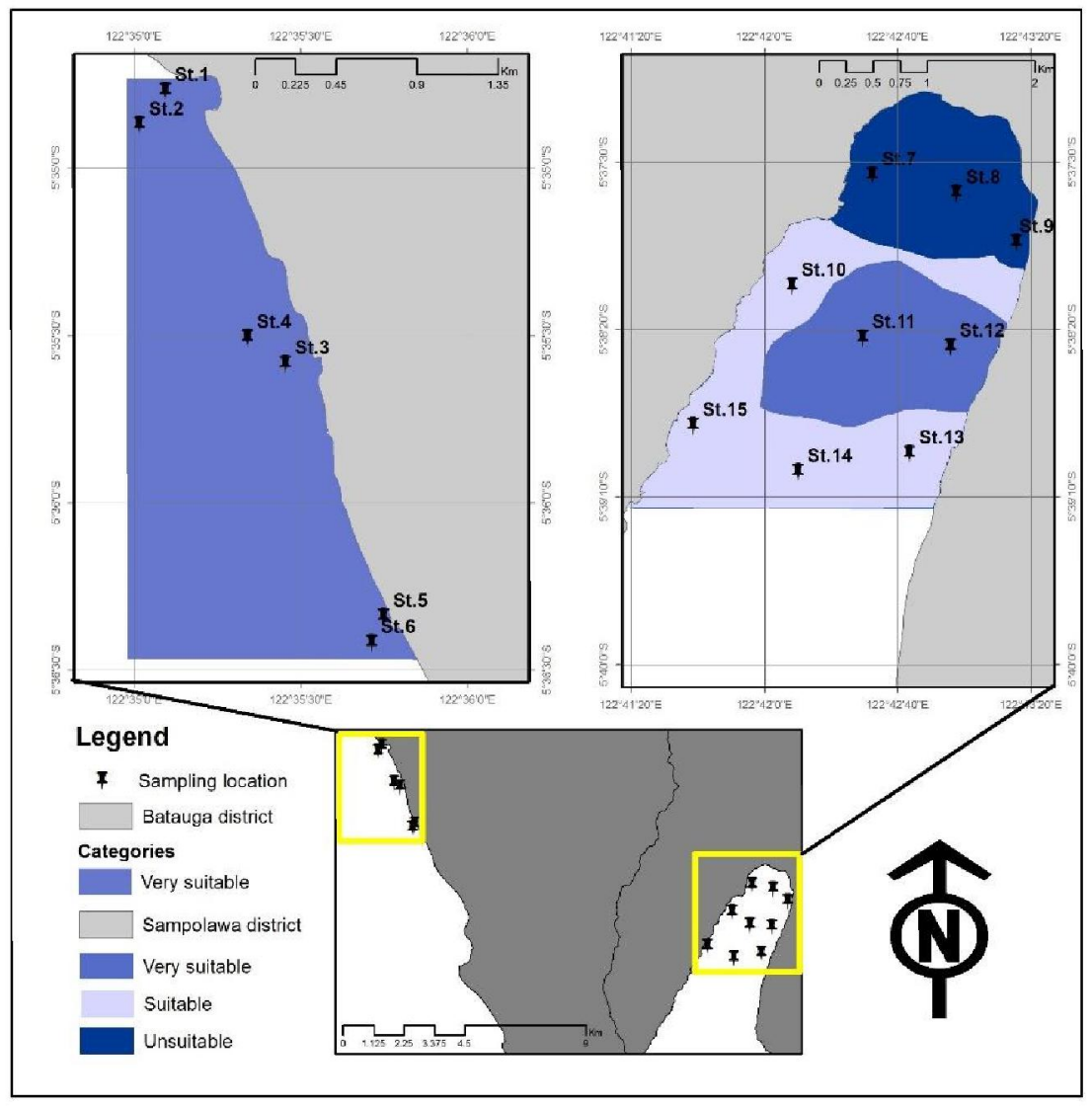

Fig 2. Suitability Map for Seaweed Cultivation

Batauga sub-district has a large enough potential for the development of seaweed cultivation. This is because the conditions of the waters based on the scoring results fall into the very suitable category, this is because almost all of the water quality parameters required for optimum growth of seaweed meet the suitability value. Meanwhile, Sampolawa Subdistrict based on the scoring results is classified into the unsuitable, suitable, and very suitable category. 3 stations are classified into the unsuitable category, this is because several water quality parameters required for optimum growth of seaweed do not meet the conformity values, namely nitrate, phosphate, ammonium, and TSS. The nutrient response plays a very important role in the growth of seaweed, especially the nitrogen and phosphate content. Kappaphycus 
International Journal Of Science, Technology \& Management

alvarezii growth rate is possitively correlated with the increase in nitrogen content in the plant and the environment of the cultivation location [25].

\section{CONCLUSION}

1. Based on the results of the analysis, there were 3 unsuitable stations because 4 parameters did not meet the requirements, namely nitrate, phosphate, ammonium, and TSS.

2. The area of water suitability for seaweed cultivation in South Buton Regency is 1,267 ha, each in the Batauga sub-district is 280 ha and Sampolawa is 987 ha.

\section{ACKNOWLEDGMENTS}

The author would like to thank the Head of the South Buton Regency Marine and Fisheries Service who has provided support in this research. We would also like to thank the head of the Laboratory of Oceanography Physics and Coastal Geomorphology, Faculty of Marine and Fisheries Sciences who has assisted in the laboratory analysis of water quality.

\section{REFERENCES}

[1] FAO. The Global Status of Seaweed Production, Trade and Utilization, Roma, 2018 Vol. 124.

[2] Marine and Fisheries Ministry, Annual Report 2018,Jakarta, 2018 p.120.

[3] Department of Marine Affairs and Fisheries, South Buton Regency, Potential of Cultivation Activities, Capture Fisheries and Fish Markets by Village / Sub-District and District of South Buton Regency in 2015, Batauga, South Buton.

[4] Sanchez-Jerez, P., Karakassis, I., Massa, F., Fezzardi, D., Anguilar Manjarrez, J., Soto, D., Chapela,R., Avila, P., Macias, J.C., Tomassetti, P., Marino, G., Borg, J.A., Franicevic,V., Yucel-Gier, G., Fleming, I.A., Biao, X., Nhhala,H., Hamza, H., Forcada, A. \& Dempster,T. Aquaculture's struggle for space: the need for coastal spatial planning and the potential benefits of allocated zones for aquacultyre (AZAs) to avoid conflict and promote sustainability. Aquaculture Environment Interaction,2016 p.8: 4154.

[5] Parenrengi, A., Rachmansyah. \& Suryati, E. Carrageenan (Karaginofit) Producing Seaweed Cultivation. Revised Edition. Research Institute for Brackish Water Aquaculture, Marine and Fisheries Research and Development Agency, Ministry of Marine Affairs and Fisheries, Jakarta, 2011, p.54.

[6] Sadhori, N.S. Seaweed Cultivation. Balai Pustaka. Jakarta, 1995 p.110.

[7] Aslan, L.M. Seaweed Cultivation, Kanisius, Yogyakarta, 1991 p.128

[8] Syamsuddin, R. Water Quality Management: Theory and Application in the Fisheries Sector. Pijar Press, Makassar, 2014 p.340.

[9] Doty, M.S. The prduction and use of Eucheuma. in: Doty, M.A., Caddy, J.F, Santilices, B. (Eds), Case Studies of Seven Commercial Seaweed Resources, FAO Fish, Tech, Pap, 281,1987 p. 123 - 161 
[10] Suniada, I.K \& Indriyawan, W.M. Study of Determination of Locations for Seaweed Cultivation Development in the Waters of Saleh Bay, Sumbawa. Journal of Tropical Fisheries and Marine Affairs, 2014, VIII (1).

[11] Budiyanto, D.A. Determination of Seaweed Cultivation Location Based on PhysicalChemical Parameters in Inner Ambon Bay, Thesis, Oceanography Study Program, Faculty of Earth Sciences and Technology, Bandung Institute of Technology, 2015.

[12] Eidman HM. Study of the effectiveness of marine algae (seaweed) seeds. one of the efforts to increase the production of marine algae (Eucheuma sp) cultivation. Research Report. IPB Faculty of Fisheries. Bogor, 1991.

[13] Glenn, E.P. and M.S. Doty. 1981. Photosynthesis and respiration of the tropical red seaweeds, Eucheuma Striatum (Tambalang and Elkhorn Varieties) and E. denticulatum. J Aquatic Botany, 1981, p.10:353-364.

[14] Sastrawijaya, A.T., Environmental pollution. Rineka Cipta, Jakarta, 2000 p.152.

[15] Ministry of Environment R.I, Decree of the State Minister for Population and Environment Number 02 of 1988 concerning Guidelines for Determining Environmental Quality Standards for Marine Biota (Aquaculture). Jakarta, 1988, p. 31.

[16] Sulistijo, The Harvest Quality of Alvarezzi Culture by Floating Method in Pari Island Nort Jakarta. Research and Development Center for Oceanology Indonesia Institut Of Science. Jakarta, 1987.

[17] Prema, D. Site selection and water quality in mariculture: CMFRI.manuel customized training Book. Karala. Central Marine Fisheries Research Institute, 2013, p.36-39.

[18] Sulistijo, Development of Seaweed Cultivation in Indonesia. In: Introduction to the Types of Indonesian Seaweed. Research and Development Center for Oceanology, Indonesian Institute of Science. Jakarta, 1996.

[19] ASEAN Marine Water Quality (AMWQ), Management Guidelines and Monitoring Manual, Jakarta, The ASEAN Secretariat, 2008 p.146.

[20] DY. D. T. and Yap, H. T, Surge Ammonium Uptake Of The Culture Seaweed Kappaphycus alvarezii (Doty) Doty (Rhodophyta, Gigartinales), J. Exp. Mar Bio. Ecol, 2001, 265: p.89-100.

[21] Sahoo, D. Dan M. Ohno. Culture of Kappaphycus alvarezii in Deep Seawater and Nitrogen enriched medium. Bull. Mar. Sci, Fish., Kochi Univ. No. 22, 2003, p. 89-96.

[22] Effendi, H. 2003. Study of Water Quality for Management of Aquatic Resources and Environment. Kanisius, Yogyakarta, 2003 p.258.

[23] Aslan, L.M. Seaweed Cultivation, Kanisius, Yogyakarta,1998 p.97.

[24] Wardoyo, S.T.H. Water Quality Criteria for Agriculture and Fisheries Purposes. Pusdi PSL-Bogor Agricultural University. Bogor, 1975 p.36.

[25] Risjani, Y. An Investigation of Reserve and Transport Nitrogen Along The Thallus of Eucheuma. Agritek, 1999, 7(4): p.69-73. 